\title{
Association of PIK3CA gene mutations with head and neck squamous cell carcinomas
}

\author{
N. KOMMINENI ${ }^{1}$, K. JAMIL ${ }^{1, *}$, U. R. PINGALI ${ }^{2}$, L. ADDALA ${ }^{3}$, V. M. ${ }^{4}$, M. NAIDU ${ }^{5}$ \\ ${ }^{1}$ Genetics Department, Bhagwan Mahavir Medical Research Centre, AC Guards, Hyderabad-500004, A.P, India; ${ }^{2}$ Clinical Pharmacology and \\ Therapeutics Department, Nizams Institute of Medical Sciences, Hyderabad-500082, A.P, India; ${ }^{3}$ Institute of Genetics and Hospital for Genetic \\ Diseases, Osmania University, Hyderabad-16, A.P,India; ${ }^{4}$ Department of Otolaryngology, Government ENT Hospital, Koti, Hyderabad, A.P, \\ India; ${ }^{5}$ Consultant, Central Institute of Unani Medicine, (CRIUM), Hyderabad -500 838, A.P, India
}

*Correspondence: Kj.bmmrc@gmail.com

Received January 3, 2014/ Accepted June 27, 2014

\begin{abstract}
The Phosphoinositide-3-kinase catalytic alpha polypeptide (PIK3CA) is an important regulator of cell signaling pathways in human cancers. Mutations in PIK3CA were found to be associated with more aggressive clinical outcome and aberrant activation of cellular mechanisms in cancers. Hence the present study aimed to understand the mutations in the PIK3CA gene in head and neck squamous cell carcinomas (HNSCC). After the approval of the Institutional Ethics Committee we recruited 129 HNSCC patients and 150 healthy controls for screening of mutations in the helical (exon9) and kinase domain (exon 20) of the PIK3CA gene using PCR, SSCP and Sanger Sequencing. We found about $60.46 \%$ of HNSCC patients and $26 \%$ of controls with the following mutations $1634 \mathrm{~A}>\mathrm{C}(\mathrm{E} 545 \mathrm{~A})$ and $3075 \mathrm{C}>\mathrm{T}(\mathrm{T} 1025 \mathrm{~T})$ in the helical and kinase domains of PIK3CA. Both these mutations $1634 \mathrm{~A}>\mathrm{C}$ and $3075 \mathrm{C}>\mathrm{T}$ were more prominent in oral cancers, advanced stages of HNSCC and tobacco plus alcohol habits $(\mathrm{p}<0.05)$. Hence, we conclude that the distribution of mutations of PIK3CA in HNSCC were associated with demographic (tobacco and alcohol) and clinical parameters (advanced stage, primary site) of HNSCC. It is possible that when this pathway is overactive due to mutations, it may reduce apoptosis and allow proliferation of the tumor cells. Therefore we propose that these mutations may serve as prognostic biomarkers, and can also be proposed as novel therapeutic targets for HNSCC.
\end{abstract}

Key words: PI3 kinase, gene polymorphism, helical domain, kinase domain, oral cancers

Head and neck squamous cell carcinomas (HNSCC) are the group of cancers that comprise soft tissue neoplasms of oral cavity (lips, nasal cavity and paranasal sinuses), pharynx, larynx and salivary glands. HNSCC accounts approximately $30 \%$ of all cancers in India [1]. Tobacco and alcohol consumption in various forms are the major preventable risk factors for HNSCC. The intensity of exposure to these carcinogens affects the incidence of this disease [2]. Our previous findings also emphasized on the importance of tobacco smoke and environmental pollutants in the incidence of lung cancer [3]. Despite advances in diagnosis and therapy, HNSCC still remains low on long term survival rates [4].The HNSCC is characterized by genetic aberrations, $[5,6]$, identifying molecular biomarkers for this devastating disease is one of the most important thrust areas of research which would eventually change the outcome of HNSCC.
Genetic alterations in Phosphatidylinositol 3 kinase (PI3K) pathway is one of the most common event in HNSCC related to disease progression and survival $[7,8]$. The PI3K's are lipid kinases that are activated by autocrine or paracrine stimulation of receptor tyrosine kinases such as the epidermal growth factor receptor (EGFR) and insulin-like growth factor-1 (IGF-1). The activated kinases catalyze the serinethreonine AKT, which stimulates the downstream signaling mechanisms for cell proliferation, survival, and apoptosis [9, 10]. The phosphoinositide-3-kinase, catalytic, alpha polypeptide (PIK3CA) gene is located on chromosome 3q26.32, and codes for the catalytic subunit p110 alpha of class 1A PI3 Kinases $[11,12]$. The aberrant PIK3CA activation plays an important role in sustaining processes important to tumor growth and development [13-15]. More recently, a high frequency of $P I K 3 C A$ mutations was reported in carcinomas 
of the colon, breast, brain, liver, stomach, lung, ovary, head and neck [16-20]. The mutated PIK3CA protein is able to activate AKT pathway even in the absence of growth factors [13]. More than $80 \%$ of these mutations are clustered in the helical (exon 9) and kinase domains (exon 20) [16]. The three most frequently reported mutation hotspots in PIK3CA (i.e., E542K, E545K, and H1047R) have been shown to elevate its lipid kinase activity and lead to the activation of the downstream signaling pathways $[10,16]$. In addition, numerous rare cancer specific mutations $(\mathrm{R} 38 \mathrm{H}, \mathrm{N} 345 \mathrm{~K}$, C420R, E545G, E545A, Q546K, Q546E, C901F, H1047L, M1043V, T1025T, G1049G, and A1046V) have also been identified in PIK3CA [16,18, 21].

The polymorphic frequencies of PIK3CA have been reported to vary among different cancers it was $32 \%$ in colon cancer, $25 \%$ in gastric cancer, $40 \%$ in breast cancer, $27 \%$ in brain cancer, $4 \%$ in lung cancer, $7 \%$ in ovarian cancer and $11 \%$ in HNSCC $[10,12,13]$. Somatic mutations and gene amplifications both contribute to the activation of PIK3CA in HNSCC [10]. Murugan AK et al, [9] reported 10.5\% of PIK3CA polymorphisms in Indian patients with small sample size, but the influence of tobacco - alcohol habits and clinico-pathological characteristics of these polymorphisms were undefined. AKT pathway activation plays a pivotal role in mediating tobacco induced HNSCC carcinogenesis [22]. We previously reported that the prevalence of EGFR polymorphisms was associated with the clinical parameters and risk factors such as tobacco and alcohol habits in HNSCC patients [23]. Thus the present study was conducted to determine the distribution of gene polymorphism in the helical (exon 9) and kinase domains (exon 20) of PIK3CA and to understand its importance in relation to demographic and clinical parameters of HNSCC in our population. Further we aim to investigate the potential of these mutations as biomarkers for prognosis or diagnosis of HNSCC, which can become novel targets for therapy.

\section{Patients and methods}

Study population. The present study is a hospital based case - control study conducted in south Indian population. The study was approved by the Institutional Ethics Committee of Bhagwan Mahavir Medical Research Centre- Hyderabad, India. Head and neck cancer patients were assessed on the basis of clinical and pathological examinations. Age and sex matched individuals were selected for control group. The clinical parameters for HNSCC includes primary cancer site, stage and grade were retrieved from medical records. All the individuals were personally interviewed to collect the demographic factors such as age, gender, occupation and personal habits (tobacco and alcohol) and the details were documented using a structured questionnaire.

Inclusion and exclusion criteria. Patients who were clinically confirmed with squamous cell carcinoma of head and neck cancers by pathologists and those patients who gave their consent were included in the study. HNSCC patients reluctant to give their consent and patients who were under the radiation plus chemotherapy treatments were excluded. The absence of pre-cancerous lesions or prior history of cancer was considered as inclusion criteria for control group.

Sample collection. Clinically confirmed 129 HNSCC tissue biopsies were collected in saline and stored at minus $80^{\circ} \mathrm{C}$ till further use. Three milliliter of blood samples were collected from 150 healthy volunteers by venipuncture. All the samples were collected with a written informed consent.

\section{Mutational analysis of PIK3CA}

Genomic DNA extraction. Genomic DNA was extracted from tissue biopsies and blood samples by ethanol precipitation protocol [24]. The quality and quantity of the DNA was analyzed by agarose gel electrophoresis and spectroscopy. The quantified DNA samples are further processed for mutational analysis using polymerase chain reaction (PCR) and single strand confirmatory polymorphism (SSCP) techniques.

Mutational analysis in helical domain (exon 9) of PIK3CA. The specific primers for exon 9 were designed using primer 3 software. The 269bp region was amplified with forward primer (F.P):CTGTGAATCCAGAGGGGAAA and reverse primer (R.P) : GCTGAGATCAGCCAAATTCA in a 50 microliter reaction mixture prepared with, $1 \mathrm{X} \mathrm{KCl}$ buffer, 1.8 millimolar $\mathrm{MgCl} 2,200$ micromolar of each dNTPs, $1.5 \mathrm{U}$ of Taq polymerase, 10 picomoles of each primer (F.P and R.P) and 100 nano grams of DNA template. The optimized conditions for PCR programme were initial denaturation at $94^{\circ} \mathrm{C}$ for $5 \mathrm{~min}$, followed by a 35 cycles reaction of denaturation at $94^{\circ} \mathrm{C}$ for $35 \mathrm{sec}$, annealing at $60^{\circ} \mathrm{C}$ for $30 \mathrm{sec}$, and extension at $72^{\circ} \mathrm{C}$ for $35 \mathrm{sec}$ with final extension at $72^{\circ} \mathrm{C}$ for 7 minutes. The quality and specificity of the $269 \mathrm{bp}$ region was confirmed with the 100bp molecular marker on $2 \%$ agarose gel electrophoresis. 10\% Polyacrylamide gels (50\% acrylamide stock, 10X buffer, 10\% ammonium per sulphate, TEMED, distilled water) were used for Single nucleotide polymorphism (SNP) analysis. The conversion of amplified double stranded DNA into single stranded DNA was done by mixing 5 microliter of the PCR product with 10 microliter of denaturation buffer (95\% formamide, 0.05\% bromophenol blue, 0.05\% xylene cyanol, EDTA and $\mathrm{NaOH}$ ) and the samples were denatured at $95^{\circ} \mathrm{C}$ for 5 minutes. The denatured samples were snap cooled on ice for about 5 minutes and immediately loaded on $10 \%$ Polyacrylamide gels. The electrophoresis was carried out for $5 \mathrm{hrs}$ at 160 volts. The gels were silver stained ( $1 \%$ silver nitrate) to observe the mobility shifts.

Mutational analysis in kinase domain (exon20) of PIK3CA. The specific primers for exon 20 were designed by primer 3 software. The $288 \mathrm{bp}$ region was amplified with the following primer sequences:

F.P : C A T T T G C T C C A A A C T G A C C A; R.P : TGTGTGGAAGATCCAATCCA in a 50 microliter reaction mixture prepared with, $1 \mathrm{X} \mathrm{KCl}$ buffer, 1.7 millimolar $\mathrm{MgCl}$, 


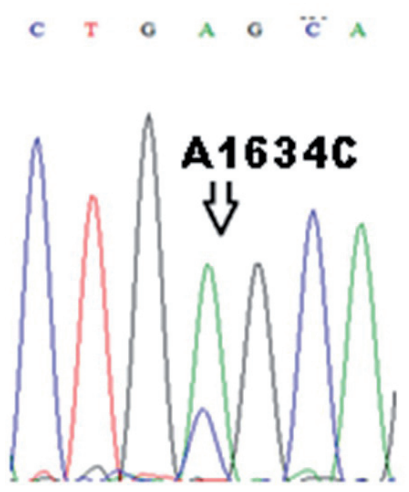

(a)

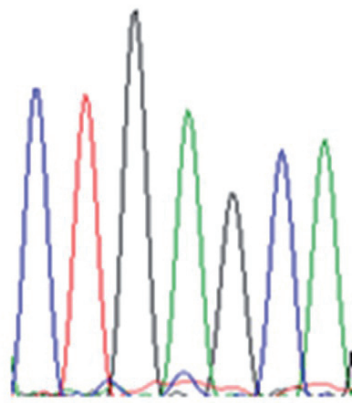

(b)

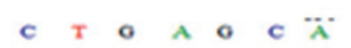

Figure 1. PIK3CA gene sequences with A1634C (E545A) mutation. Notes: (a) Hetero sequence of A1634C transversion (b) Normal sequence.

200 micromolar of each dNTPs, $1.5 \mathrm{U}$ of Taq polymerase, 10 picomoles of each primer and 100 nano grams of DNA template. The optimized conditions for PCR programme were initial denaturation at $94^{\circ} \mathrm{C}$ for $5 \mathrm{~min}$, followed by a 35 cycle reaction of denaturation at $94^{\circ} \mathrm{C} / 40 \mathrm{sec}$, annealing at $60^{\circ} \mathrm{C} / 30 \mathrm{sec}$, and extension at $72^{\circ} \mathrm{C} / 40 \mathrm{sec}$ with final extension at $72^{\circ} \mathrm{C}$ for 7 minutes on eppendorf thermal cycler. The quality and specificity of the amplified exon 20 region was confirmed on the $2 \%$ agarose gel electrophoresis with 100bp molecular marker. 12\% Polyacrylamide gels (50\% acrylamide stock, $10 \mathrm{X}$ buffer, $10 \%$ ammonium per sulphate, TEMED, distilled water) were used for the SSCP analysis. 5 microliter of PCR products were mixed with 10 microliter of denaturation buffer and denatured at $95^{\circ}$ for 5 minutes. The denatured samples were snap cooled and loaded on the gels. The gel run was carried out at 160 volts for 6 hours. The gels were silver stained ( $1 \%$ silver nitrate) to observe the mobility shifts.

Sequencing. Samples with variant mobility shifts were processed for sequencing with Sanger's dideoxy method. The sequenced forward and reverse strands were further analyzed for SNP's. The sequence variations were confirmed with the help of wild type sequence. The samples were repeatedly processed to confirm the SNP's and its associated aminoacid changes in the codons of the PIK3CA.

Statistical analysis. The statistical analysis was carried out with med calc version 12.1.1.2. The clinical characteristics were expressed as percentages. The Fisher's exact test, odds ratio's and chi-square tests were performed to evaluate the association of HNSCC disease with the demographic and clinical parameters as appropriate. Relative risk analysis was performed in the individuals with tobacco and alcohol habits. A two-tailed P-value was used in all the analysis, and a P-value $<0.05$ was considered statistically significant.

\section{Results}

Patient characteristics. The 129 HNSCC cases and 150 healthy volunteers formed our study group. Three groups of squamous cell carcinomas were observed which include well differentiated squamous cell carcinomas (WDSCC), medium differentiated squamous cell carcinomas (MDSCC), and poorly differentiated squamous cell carcinomas (PDSCC). Equal male female ratio was recorded. The primary site of the HNSCC disease was oral cancers (54.26\%), followed by oropharyngeal tumors (27.13\%), sinonasal cancers (12.40\%) and laryngeal cancers (6\%). The majority of HNSCC were at stage III (41.86\%) and stage IV (32.55\%) followed by $20.93 \%$ at stage II and $4 \%$ at stage I. Overall, tobacco and alcohol consumers were found to be highest in HNSCC cases (87.59\%) than controls (46\%). The median age was $50,31 \%$ of HNSCC were less than 50 years whereas $68.99 \%$ were under equal or greater than 50 years of age.

Mutational analysis of PIK3CA. A total of 129 HNSCC cases and 150 healthy volunteers of our study group were screened for PIK3CA gene mutations. Helical and kinase domains of PIK3CA were hot spot regions of mutations, so both the exons (exon 9 and exon 20) of PIK3CA were studied for mutations.

Mutation analysis in helical domain of PIK3CA. In exon 9 we found a transversion of adenine to cytosine at nucleotide 1634 loci that created a missense mutation which replaces glutamate at 545 codon with alanine (E545A). The heterozygous nucleotide sequence was showed in figure 1 .

The frequency of $1634 \mathrm{~A}>\mathrm{C}(\mathrm{E} 545 \mathrm{~A})$ mutation in HNSCC cases was $46.51 \%$ and $19.33 \%$ in controls. The mutant allele AC was found to be significant in disease group whereas the wild type allele AA was more prevalent in control group $(\mathrm{p}<0.0001)$. The distribution of mutations among HNSCC and controls, in relation with demographic factors (gender, habits and age) and the significant polymorphic differences in the study group are shown in Table 1 . The mutant allele (AC) was more significant in HNSCC with tobacco and alcohol habits (OR: 2.12; CI: 1.1587-3.9107; p=0.01).The mutations of PIK3CA were significantly associated with the tobacco and alcohol habits of the HNSCC patients, and our findings also showed significant difference in the distribution of mutations among controls (males) with tobacco and alcohol habits (versus controls with no habits of tobacco and alcohol; OR: 6.494; CI: 2.3201-18.1771; $\mathrm{p}=0.0004)$.

We extended our analysis to understand the prevalence of polymorphisms in association with all the clinical parameters (primary site, tumor grade, and tumor stage). The distribution of polymorphisms among gender in relation to clinical parameters is presented in Table 2. Chi square analysis showed a significant difference in the occurrence of mutation with the primary site of the disease $(\mathrm{p}=0.007)$. The mutant allele AC was more significant in advanced stages than early stage HNSCC $(\mathrm{p}=0.004)$. We did not find significant difference among gender in relation to clinical parameters and age of the 
Table 1. The association of PIK3CA gene mutation 1634A $>C$ (E545A) with the demographic parameters of the study group.

\begin{tabular}{|c|c|c|c|c|c|}
\hline \multirow[b]{2}{*}{ Demographics } & \multicolumn{2}{|c|}{ HNSCC $\operatorname{cases}(\mathrm{n}=129)$} & \multicolumn{2}{|c|}{ Controls $(\mathrm{n}=150)$} & \multirow{2}{*}{ p-value } \\
\hline & $\begin{array}{l}\text { Mutant } \\
(\mathrm{n}=60)\end{array}$ & $\begin{array}{l}\text { Wild } \\
(\mathrm{n}=69)\end{array}$ & $\begin{array}{l}\text { Mutant } \\
(\mathrm{n}=29)\end{array}$ & $\begin{array}{c}\text { Wild } \\
(\mathrm{n}=121)\end{array}$ & \\
\hline \multicolumn{6}{|l|}{ Gender } \\
\hline Male & $30(46.15 \%)$ & $35(53.84 \%)$ & $24(32 \%)$ & $51(68 \%)$ & 0.08 \\
\hline Female & $30(46.87 \%)$ & $30(53.12 \%)$ & $5(5 \%)$ & $69(92 \%)$ & $0.0001^{*}$ \\
\hline \multicolumn{6}{|l|}{ Habits } \\
\hline None & $4(25 \%)$ & $12(75 \%)$ & - & $84(100 \%)$ & $0.006^{*}$ \\
\hline Smoking & $3(42.85 \%)$ & $4(57.14 \%)$ & $1(20 \%)$ & $4(80 \%)$ & 0.41 \\
\hline Alcohol & $1(50 \%)$ & $1(50 \%)$ & - & $7(100 \%)$ & 0.14 \\
\hline Chewers & $16(45.71 \%)$ & $19(54.28 \%)$ & $2(100 \%)$ & - & 0.26 \\
\hline S\&A & $9(40.90 \%)$ & $13(59.09 \%)$ & $16(47.05 \%)$ & $18(52.94 \%)$ & 0.65 \\
\hline S\&C & $1(50 \%)$ & $1(50 \%)$ & $1(100 \%)$ & - & 0.58 \\
\hline $\mathrm{A} \& \mathrm{C}$ & $19(61.29 \%)$ & $12(38.70 \%)$ & $4(40 \%)$ & $6(60 \%)$ & 0.24 \\
\hline $\mathrm{S}, \mathrm{A} \& \mathrm{C}$ & $7(50 \%)$ & $7(50 \%)$ & $5(40 \%)$ & $2(28.57 \%)$ & 0.35 \\
\hline \multicolumn{6}{|l|}{ Age Group } \\
\hline$<50$ & $18(45 \%)$ & $22(55 \%)$ & $13(19.11 \%)$ & $55(80.88 \%)$ & $0.005^{*}$ \\
\hline$\geq 50$ & $42(47.19 \%)$ & $47(52.80 \%)$ & $16(19.51 \%)$ & $66(80.48 \%)$ & $0.0002^{*}$ \\
\hline
\end{tabular}

Notes: Smoking: Tobacco smoking; Chewers: tobacco chewers; S\&A: tobacco smoking and alcohol; S\&C: tobacco smoking and tobacco chewers; A\&C: alcohol and tobacco chewers; S, A \&C: tobacco smoking, alcohol and tobacco chewers; $\$$ odds ratio; ${ }^{*} \mathrm{p}<0.05$ considered statistically significant.

Table 2. The association of PIK3CA gene mutation A1634C (E545A) with the clinical parameters of HNSCC.

\begin{tabular}{|c|c|c|c|c|c|c|}
\hline \multirow[b]{2}{*}{ S.no } & \multirow[b]{2}{*}{ Clinical parameters } & \multicolumn{2}{|c|}{ Males $(n=65)$} & \multicolumn{2}{|c|}{ Females $(n=64)$} & \multirow[b]{2}{*}{ p-value ${ }^{*}$} \\
\hline & & $\begin{array}{l}\text { Mutant } \\
(\mathrm{n}=30)\end{array}$ & $\begin{array}{l}\text { Wild } \\
(\mathrm{n}=35)\end{array}$ & $\begin{array}{l}\text { Mutant } \\
(\mathrm{n}=30)\end{array}$ & $\begin{array}{c}\text { Wild } \\
(\mathrm{n}=34)\end{array}$ & \\
\hline \multirow[t]{5}{*}{1} & Primary site & & & & & \\
\hline & Oral cancers & $19(52.77 \%)$ & $17(47.22 \%)$ & $18(52.94 \%)$ & $16(47.05 \%)$ & 0.98 \\
\hline & Oropharyngeal cancers & $8(50.00 \%)$ & $8(50.00 \%)$ & $11(57.89 \%)$ & $8(42.10 \%)$ & 0.64 \\
\hline & Sinonasal cancers & $3(42.85 \%)$ & $4(57.14 \%)$ & $1(11.11 \%)$ & $8(88.88 \%)$ & 0.17 \\
\hline & Larynx cancer & - & $6(100 \%)$ & - & $2(100 \%)$ & - \\
\hline \multirow[t]{4}{*}{2} & Tumor Grade & & & & & \\
\hline & WDSCC & $18(45.00 \%)$ & $22(55 \%)$ & $23(50.00 \%)$ & $23(50.00 \%)$ & 0.64 \\
\hline & MDSCC & $9(52.94 \%)$ & $8(47.05 \%)$ & $5(33.33 \%)$ & $9(66.66 \%)$ & 0.34 \\
\hline & PDSCC & $3(37.50 \%)$ & $5(62.50 \%)$ & $2(66.66 \%)$ & $1(33.33 \%)$ & 0.39 \\
\hline \multirow[t]{3}{*}{3} & Tumor stage & & & & & \\
\hline & Stage I \&II & $2(12.50 \%)$ & $14(87.50 \%)$ & $6(35.29 \%)$ & $11(64.70 \%)$ & 0.14 \\
\hline & Stage III \&IV & $28(57.14 \%)$ & $21(42.85 \%)$ & $24(51.06 \%)$ & $23(48.93 \%)$ & 0.55 \\
\hline
\end{tabular}

\# Odds ratio

HNSCC patients. E545A was found to be significant in HNSCC among both the age groups ( $<50$ and $\geq 50$ years; Table 1 ) but was not found with any significant difference in the occurrence of mutation in HNSCC among these age groups. These findings suggested that the E545A mutation is not specific to certain age but is more specific to advanced stages of the HNSCC.

Mutational analysis of kinase domain (exon20) in PIK3CA. We found a silent mutation in the kinase domain of PIK3CA gene. A transition of cytosine to thymine (Figure 2) at 3075 nucleotide created a silent mutation at 1025 codon in the kinase domain of PIK3CA.

We found $41 \%$ of HNSCC patients and $16 \%$ of controls with silent mutation. In HNSCC three genotypes were found for $3075 \mathrm{C}>\mathrm{T}$ polymorphism in exon 20; CC (58.91\%), CT $(22.48 \%)$ and TT (18.60\%). The wild type allele CC was more significant in controls whereas mutant alleles (CT and TT) were more significant in HNSCC patients $(\mathrm{p}<0.0001)$. The distribution of mutation among HNSCC cases and controls in association with demographic parameters are presented in Table 3. Tobacco smoking, tobacco chewing and alcohol habits in combination showed significant association with HNSCC cases (OR: 0.22; 95\%CI-0.05972 to 0.8649). The mutant alleles (CT and TT) of 3075C $>$ T were significant among males (OR: 6.9028; CI: 2.2381-21.29; $\mathrm{p}=0.0008$ ) than females in the control group. The relative risk ratio was significant in the tobacco and alcohol habituated control group $(\mathrm{p}=0.0004)$. 
$A G A C C C T A G C C$ A G A C T C T A G C C C A G A C T C I A G C C

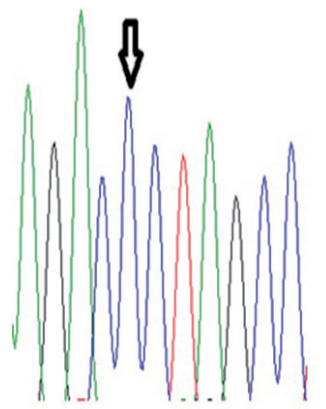

(A)

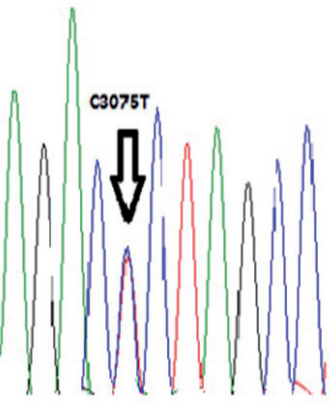

(B)

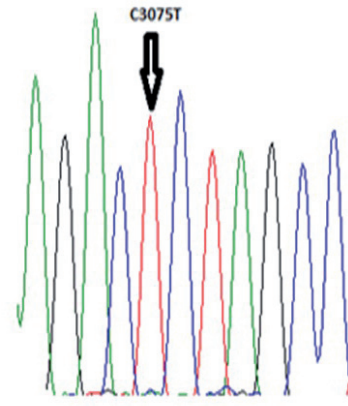

(c)

Figure 2. PIK3CA gene sequences with C3075T (T1025T) mutation.

Notes: (a) Presenting a normal sequence (b) heterozygous state at 3075 nucleotide with cytosine and thymine (c) Homozygous polymorphism at 3075 nucleotide created by replacing thymine with cytosine.

The clinical parameters of HNSCC such as primary site, tumor grade, and tumor stage along with the mutational frequencies of exon 20 in relation to gender are presented in Table 4 . We found a significant association of $3075 \mathrm{C}>\mathrm{T}$ mutation with the advanced stage of the disease $(\mathrm{p}=0.002)$. Chi square analysis showed a significant difference in the distribution of mutation in relation to primary site of the disease $(\mathrm{p}=0.007)$. $\geq 50$ years age group showed significant difference among HNSCC versus controls (Table 3 ) and these results are also suggesting that the PIK3CA mutation $3075 \mathrm{C}>\mathrm{T}(\mathrm{T} 1025 \mathrm{~T})$ was specific to HNSCC and not to any particular age groups $(<50$ or $\geq 50$ years).

Mutations of PIK3CA. The overall mutational frequency was found to be $60.46 \%$ in HNSCC cases and $26 \%$ in controls. The mutational frequency of each exon is presented in Table 5. Though the study group had similar male/ female ratio the observed polymorphic frequency was higher in females (67.18\%) than in males (55.38\%). 68.75\% of MDSCC, $60.46 \%$ of WDSCC and $45.45 \%$ of PDSCC were identified with polymorphisms. These SNPs were significantly associated with

Table 3. The association of PIK3CA gene mutation 3075C $>\mathrm{T}$ (T1025T) with the demographic parameters of the study group.

\begin{tabular}{|c|c|c|c|c|c|}
\hline \multirow[b]{2}{*}{ Demographics } & \multicolumn{2}{|c|}{ HNSCC cases $(\mathrm{n}=129)$} & \multicolumn{2}{|c|}{ Controls $(\mathrm{n}=150)$} & \multirow[b]{2}{*}{ p-value ${ }^{*}$} \\
\hline & $\begin{array}{l}\text { Mutant } \\
(\mathrm{n}=53)\end{array}$ & $\begin{array}{l}\text { Wild } \\
(n=76)\end{array}$ & $\begin{array}{l}\text { Mutant } \\
(\mathrm{n}=25)\end{array}$ & $\begin{array}{l}\text { Wild } \\
(\mathrm{n}=125)\end{array}$ & \\
\hline \multicolumn{6}{|l|}{ Gender } \\
\hline Male & $22(33.84 \%)$ & $43(66.15 \%)$ & $21(28 \%)$ & $54(72 \%)$ & 0.40 \\
\hline Female & $31(48.43 \%)$ & $33(51.56 \%)$ & $4(5 \%)$ & $71(92 \%)$ & $0.0001^{*}$ \\
\hline \multicolumn{6}{|l|}{ Habits } \\
\hline None & $3(18.75 \%)$ & $13(81.25 \%)$ & $2(2 \%)$ & $82(97.61 \%)$ & $0.01^{*}$ \\
\hline Smoke & $3(42.85 \%)$ & $4(57.14 \%)$ & $1(20 \%)$ & $4(80 \%)$ & 0.41 \\
\hline Alcohol & $1(50 \%)$ & $1(50 \%)$ & $1(16.66 \%)$ & $6(85.71 \%)$ & 0.31 \\
\hline Chewers & $19(54.28 \%)$ & $16(45.71 \%)$ & $1(50 \%)$ & $1(50 \%)$ & 0.90 \\
\hline S\&A & $10(45.45 \%)$ & $12(54.54 \%)$ & $13(38.23 \%)$ & $21(61.76 \%)$ & 0.59 \\
\hline S\&C & $1(50 \%)$ & $1(50 \%)$ & - & $1(100 \%)$ & 0.58 \\
\hline $\mathrm{A} \& \mathrm{C}$ & $14(45.16 \%)$ & $12(54.83 \%)$ & $2(20 \%)$ & $8(80 \%)$ & 0.17 \\
\hline $\mathrm{S}, \mathrm{A} \& \mathrm{C}$ & $2(14.28 \%)$ & $12(81.25 \%)$ & $5(71.42 \%)$ & $2(28.57 \%)$ & $0.01^{*}$ \\
\hline \multicolumn{6}{|l|}{ Age Group } \\
\hline$<50$ & $14(35 \%)$ & $26(65 \%)$ & $16(23.52 \%)$ & $52(76.47 \%)$ & 0.20 \\
\hline$\geq 50$ & $39(43.82 \%)$ & $50(56.17 \%)$ & $9(10.97 \%)$ & $73(89.02 \%)$ & $<0.0001^{*}$ \\
\hline
\end{tabular}

Notes: Smoking: Tobacco smoking; Chewers: tobacco chewers; S\&A: tobacco smoking and alcohol; S\&C: tobacco smoking and tobacco chewers; A\&C: alcohol and tobacco chewers; S, A \&C: tobacco smoking, alcohol and tobacco chewers; $\$$ odds ratio; ${ }^{*}<0.05$ considered statistically significant. 
Table 4. The association of PIK3CA gene mutation 3075C $>\mathrm{T}$ (T1025T) with the clinical parameters of HNSCC.

\begin{tabular}{|c|c|c|c|c|c|c|}
\hline \multirow[b]{2}{*}{ S.no } & \multirow[b]{2}{*}{ Clinical parameters } & \multicolumn{2}{|c|}{ Males $(\mathrm{n}=65)$} & \multicolumn{2}{|c|}{ Females $(\mathrm{n}=64)$} & \multirow[b]{2}{*}{ p-value ${ }^{*}$} \\
\hline & & $\begin{array}{l}\text { Mutant } \\
(\mathrm{n}=22)\end{array}$ & $\begin{array}{l}\text { Wild } \\
(\mathrm{n}=43)\end{array}$ & $\begin{array}{c}\text { Mutant } \\
(\mathrm{n}=31)\end{array}$ & $\begin{array}{l}\text { Wild } \\
(\mathrm{n}=33)\end{array}$ & \\
\hline \multirow[t]{5}{*}{1} & Primary site & & & & & \\
\hline & Oral cancers & $16(44.44 \%)$ & $20(55.55 \%)$ & $20(58.82 \%)$ & $14(41.17 \%)$ & 0.23 \\
\hline & Oropharyngeal cancers & $4(25.00 \%)$ & $12(75 \%)$ & $10(52.63 \%)$ & $9(47.36 \%)$ & 0.1 \\
\hline & Sinonasal cancers & $2(28.57 \%)$ & $5(71.42 \%)$ & $1(11.11 \%)$ & $8(88.88 \%)$ & 0.38 \\
\hline & Larynx cancer & - & $6(100 \%)$ & - & $2(100 \%)$ & - \\
\hline \multirow[t]{4}{*}{2} & Tumor Grade & & & & & \\
\hline & WDSCC & $14(35 \%)$ & $26(65 \%)$ & $21(45.65 \%)$ & $25(54.34 \%)$ & 0.31 \\
\hline & MDSCC & $6(35.29 \%)$ & $11(64.70 \%)$ & $10(66.66 \%)$ & $5(33.33 \%)$ & 0.08 \\
\hline & PDSCC & $2(25.00 \%)$ & $6(75 \%)$ & - & $3(100 \%)$ & 0.65 \\
\hline \multirow[t]{3}{*}{3} & Tumor stage & & & & & \\
\hline & Stage I \&II & $5(31.25 \%)$ & $11(68.75 \%)$ & $2(11.76 \%)$ & $15(88.23 \%)$ & 0.18 \\
\hline & Stage III \&IV & $17(34.69 \%)$ & $32(65.30 \%)$ & $29(61.70 \%)$ & $18(38.29 \%)$ & $0.0001^{*}$ \\
\hline
\end{tabular}

Notes: ${ }^{*}$ odds ratio; ${ }^{*} \mathrm{p}<0.05$.

Table 5. Mutations of PIK3CA gene in the study group.

\begin{tabular}{lccccccc}
\hline Exon & Domain & Nucleotide & Amino acid & Mutation & HNSCC (n \%) & Controls $(\mathrm{n} \%)^{\mathrm{p} \text {-value }}$ \\
\hline 9 & Helical & A1634C & E545A & Missense & $60 / 129(46.51 \%)$ & $29 / 150(19.33 \%)$ & $\mathrm{p}<0.0001^{*}$ \\
20 & Kinase & C3075T & T1025T & Silent & $53 / 129(41.08 \%)$ & $25 / 150(16.66 \%)$ & $\mathrm{p}<0.0001^{*}$ \\
\hline
\end{tabular}

Note: ${ }^{\circledR}$ Fisher exact test, ${ }^{*} \mathrm{p}<0.05$.

Oral cancers (OR: 2.25; CI: 1.0953-4.645, $\mathrm{p}=0.02$ ), and Sino nasal cancers (OR: 0.2396; CI: 0.7769-0.738 71; $\mathrm{p}=0.01$ ). The PIK3CA gene was found to be polymorphic in the advanced stages of HNSCC ( $p=0.003$, OR: 0.2955; CI: 0.13-0.6714). The frequency of mutation was $62.92 \%(56 / 89)$ in $\geq 50$ years of age group, and 55\% (22/40) in <50years in HNSCC. Both age groups of HNSCC, that include $<50$ years $(\mathrm{p}=0.01)$ and $\geq 50$ years $(\mathrm{p}<0.0001)$ showed significant difference with controls in the incidence of PIK3CA mutations. Tobacco and alcohol were major risk factors for HNSCC and associated in inducing gene aberrations. Hence we could record a significant association (OR: 0.23; 95\%CI-0.07769-0.7387; $\mathrm{p}=0.01$ ), of mutations in HNSCC patients with tobacco and alcohol habits.

\section{Discussion}

PIK3CA is one of the most important downstream regulators of EGFR cell signaling that could interrupt the normal cell proliferation and induces carcinogenesis. Abnormal EGFRPI3K pathway is involved in cell proliferation, survival, and migration of tumor cells [25]. Over expression and mutations of PIK3CA have been reported in several human cancers, including HNSCC [10]. PIK3CA alterations have been associated with cancer recurrence [26]; metastasis $[12,13]$ and poor prognosis $[27,28]$ in a variety of human cancers. In HNSCC, PIK3CA alterations correlate with advanced stage $[29,30]$, vascular invasion [31], and lymph node metastasis [32]. In our study we found a higher mutational frequency of PIK3CA (E545A-46.51\% and T1025T-41.08\%) in HNSCC. In literature relatively higher frequency $(16.1 \%)$ of polymorphisms in PIK3CA were found in oral squamous cell carcinomas (OSCC) with stage IV of the disease suggesting that PIK3CA mutations may be a late event in genomic aberration involved in the progression of OSCC [29]. Our results also found a significant association of PIK3CA mutations with oral cancers $(\mathrm{p}>0.05)$ than other primary sites and confirmed the role of PIK3CA in oral carcinogenesis. The socio economic conditions, greater consumption of tobacco and alcohol plus advanced stages of the disease in HNSCC were possible risk factors for higher prevalence of mutations in oral cancers in our study group.

Karakas B et al., [33] reviewed that the activation of PI3K by a growth factor bound (activated) receptor tyrosine kinase (RTK) which drives various downstream processing that regulate a number of cellular functions including those involved in tumor development and progression. The aberrant activation of the PIK3CA is an early event in oncogenesis associated with progression of dysplasia into invasive squamous cell carcinoma of HNSCC $[13,30]$. The mutational frequency in this gene was directly proportional to the advanced stage of HNSCC, hence we could observe significant association of these point mutations in HNSCC ( $p>0.05)$. The metabolites of tobacco and alcohol have a tendency to bind to DNA and form DNA adducts that leads to gene mutations and gene instability. Earlier we reported the role of CYP1A1, XRCC1, 
GSTM1 and GSTT1 genes and their genotypes in elevating the tobacco induced carcinogenesis in head and neck cancers [34-36]. In the present study we found also higher prevalence of mutations in tobacco smokers, tobacco chewers and alcohol drinkers in our study group. Further the control group with combination of tobacco and alcohol were at greater risk of these mutations indicating that they might be vulnerable to the disease. From the above results it is evident that tobacco and alcohol metabolites induce gene instability through mutations which increased the incidence of HNSCC disease as well as the prevalence of PIK3CA gene mutations.

Lluis Catasus et al., [37] found that tumor grade varied significantly according to the distribution of PIK3CA mutations between exons 9 and 20. In our investigation we found that the E545A mutation was more associated with WDSCC, and T1025T mutation was more associated with MDSCC. PIK3CA mutations in human tumors are somatic, cancer specific and heterozygous $[9,38]$. In our investigation we found both homo as well as heterozygous polymorphisms for T1025T, whereas for E545A we found heterozygous polymorphism. The two mutations such as E545G, E545K contribute to increased lipid kinase activity in tumor cells [9]. E545A mutations were reported to be $15.06 \%$ in hepatocellular carcinoma and $88 \%$ in ovarian cancers $[16,39] .1 \%$ of T1025A was reported in endometrial cancer. E545A and T1025S were rare cancer specific mutations of PIK3CA showing a gain of function in the lipid kinase activity of the protein [40]. Rare cases of double mutations have also been reported in gastric and breast cancers $[41,42]$ and recent investigations suggest that mutations located in the same exon do not produce an additive gain of function, whereas mutations in different exons increased the kinase activity [40]. Protein Kinases are key regulators of cell function that constitute one of the largest and most functionally diverse gene families. By adding phosphate groups to substrate proteins, they direct the activity, localization and overall function of many proteins, and serve to orchestrate the activity of almost all cellular processes. Kinases are particularly prominent in signal transduction and co-ordination of complex functions such as the cell cycle.

A statistically significant correlation between the presence of PIK3CA mutations and the presence of nodal metastasis in breast carcinoma was reported by Saal LH et al., [12] and Ichiro Akagi et al., [13]. These findings indicate that PIK3CA is directly involved in tumor development and that the PIK3CA gene itself may act as an oncogene [13,43]. PIK3CA is a putative oncogene in esophageal squamous cell carcinoma [13]. The activation of PIK3CA due to mutation, rather than amplification, may strongly contribute to the deregulation of the PI3K-AKT signaling pathway in the advanced progression, especially stage IV, of OSCC [29]. Our study also emphasized on that the PIK3CA mutations may affect the development and invasion of the disease.

The analysis of PIK3CA polymorphism in HNSCC produced a comprehensible data on the distribution of prevalent point mutations in our study group, and also its association with the clinical and demographic parameters. From these findings we concluded that the mutations of PIK3CA gene were associated with advanced stages of HNSCC and tobacco plus alcohol habits of the study group (both cases and controls). Thus the mutations of PIK3CA could serve as molecular biomarkers to understand the progressive disease of HNSCC and also for the risk assessment to this aggressive disease in tobacco plus alcohol habituated individuals.

Acknowledgements: The authors are grateful to all the patients and volunteers who formed the study group and to the Oncologists and pathologists who encouraged us in the study. The authors are grateful to SSLS life sciences Pvt. Ltd., and Bhagwan Mahavir Medical Research Centre, Hyderabad, A.P, India for the facilities.

\section{References}

[1] MEHROTRA R, SINGH M, GUPTA RK, SINGH M, KAPOOR AK. Trends of prevalence and pathological spectrum of head and neck cancers in North India. Indian J Cancer 2005; 42: 89-93. http://dx.doi.org/10.4103/0019-509X.16698

[2] HASHIBE M , BRENNAN P, CHUANG SC, BOCCIA S, CASTELLSAQUE. $X$ et al. Interaction between tobacco and alcohol use and the risk of head and neck cancer: pooled analysis in the International Head and Neck Cancer Epidemiology Consortium. Cancer Epidemiol Biomarkers Prev 2009; 18: 541-550. http://dx.doi.org/10.1158/1055-9965.EPI-08-0347

[3] KIRMANI N, JAMIL K, NAIDU MUR. Occupational and environmental carcinogens in epidemiology of lung cancer in South Indian population Biology and Medicine 2010; 2: $1-11$.

[4] HARDISSON D. Molecular pathogenesis of head and neck squamous cell carcinoma. Eur Arch Otorhinolaryngol 2003; 260: 502-508. http://dx.doi.org/10.1007/s00405-003-0581-3

[5] HERMSEN M, ALONSO GUERVOS M, MEIJER G, VAN DIEST P, SUAREZ NIETO C, et al. Chromosomal changes in relation to clinical outcome in larynx and pharynx squamous cell carcinoma. Cell Oncol 2005; 27: 191-198.

[6] SPARANO A, QUESNELLE KM, KUMAR MS, WANG Y, SYLVESTER AJ, et al. Genome wide profiling of oral squamous cell carcinoma by array-based comparative genomic hybridization. Laryngoscope 2006; 116: 735-741. http:// dx.doi.org/10.1097/01.mlg.0000205141.54471.7f

[7] MOLINOLO AA, AMORNPHIMOLTHAM P, SQUARIZE $\mathrm{CH}, \mathrm{CASTILHO}$ RM, PATEL V et al. Dysregulated molecular networks in head and neck carcinogenesis. Oral Oncology 2009; 45: 324-334. http://dx.doi.org/10.1016/j.oraloncology.2008.07.011

[8] LEEMANS CR, BRAAKHUIS BJ, AND BRAKENHOFF RH. The molecular biology of head and neck cancer, Nature Reviews Cancer 2010; 11: 9-22. http://dx.doi.org/10.1038/nrc2982

[9] MURUGAN AK, NGUYEN THI HONG, YASUHISA FUKUI, ARASAMBATTU KANNAN MUNIRAJAN AND NOBUO TSUCHIDA. Oncogenic mutations of the PIK3CA gene in head and neck squamous cell carcinomas int $\mathrm{j}$ oncol 2008; 32: 101-111. 
[10] WANGLONG QIU,FRANK SCHO NLEBEN,XIAOJUN LI,DANIELJ. Ho,Lanny G. Close, et al. PIK3CA Mutations in Head and Neck Squamous Cell Carcinoma. Clin Cancer Res 2006; 12: 1441-1446. http://dx.doi.org/10.1158/1078-0432. CCR-05-2173

[11] KATSUHIKO NOSHO, TAKAKO KAWASAKI, MUTSUKO OHNISHI, YUKO SUEMOTO, GREGORY J.KIRKNER et al. PIK3CA Mutation in Colorectal Cancer: Relationship with Genetic and Epigenetic Alterations. Neoplasia 2008; 10: 534-541.

[12] SAAL LH, HOLM K, MAURER M, MEMEO L, SU T et al. PIK3CA mutations correlate with hormone receptors, node metastasis, and ERBB2, and are mutually exclusive with PTEN loss in human breast carcinoma, " Cancer Research 2005; 65: 2554-2559. http://dx.doi.org/10.1158/0008-5472CAN-04-3913

[13] ICHIRO AKAGI, MASAO MIYASHITA, HIROSHI MAKINO, TSUTOMU NOMURA, NOBUTOSHI HAGIWARA et al. Overexpression of PIK3CA is associated with lymph node metastasis in esophageal squamous cell carcinoma, Int j onco 2009; 34: 767-775.

[14] GUO XN, RAJPUT A, ROSE R, HAUSER J, BEKO A, et al. Mutant PIK3CA-bearing colon cancer cells display increased metastasis in an orthotopic model. Cancer Res 2007; 67: 5851-5858. http://dx.doi.org/10.1158/0008-5472.CAN-07$\underline{0049}$

[15] CANTLEY LC. The phosphoinositide 3-kinase pathway. Science 2002; 296: 1655-1657. http://dx.doi.org/10.1126/ science.296.5573.1655

[16] LEVINE DA, BOGOMOLNIY F, YEE CJ, LASH A, BARAKAT RR, et al. Mutation of the PIK3CA gene in ovarian and breast cancers. Clin Cancer Res 2005; 11: 2875-2878. http:// dx.doi.org/10.1158/1078-0432.CCR-04-2142

[17] VELHO S, OLIVEIRA C, FERREIRA A, FERREIRA AC, SURIANO G et al. The prevalence of PIK3CA mutations in gastric and colon cancer. Eur JCancer 2005; 41: 1649-1654. http://dx.doi.org/10.1016/j.ejca.2005.04.022

[18] SAMUELS Y, WANG Z, BARDELLI A, SILLIMAN N, PTAK J et al. High frequency of mutations of the PIK3CA gene in human cancers. Science 2004; 304: 554. http://dx.doi. org/10.1126/science. 1096502

[19] BACHMAN KE, ARGANI P, SAMUELS Y, SILLIMAN N, PTAK J et al. The PIK3CA gene is mutated with high frequency in human breast cancers. Cancer Biol Ther 2004; 3: 772-775. http://dx.doi.org/10.4161/cbt.3.8.994

[20] BRODERICK DK, DI C, PARRETT TJ, SAMUELS YR, CUMMINS JM, et al. Mutations of PIK3CA in anaplastic oligodendrogliomas, high-grade astrocytomas, and medulloblastomas. Cancer Res 2004; 64: 5048-5050. http://dx.doi. org/10.1158/0008-5472.CAN-04-1170

[21] CAMPBELl IG, RUSSELL SE, CHOONG DY, MONTGOMERY KG, CIAVARELLA ML et al. Mutation of the PIK3CA gene in ovarian and breast cancer. Cancer Res 2004; 64: 7678-7681. http://dx.doi.org/10.1158/0008-5472.CAN$\underline{04-2933}$

[22] WEBER SM, BORNSTEIN S,LI Y, MALKOSKI SP, WANG D et al. "Tobacco-specific carcinogen nitrosamine 4-(methylnitrosamino)-1-(3-pyridyl)-1-butanone induces AKT activation in head and neck epithelia," International Journal of Oncology 2011; 39: 1193-1198.

[23] NAGALAKSHMI, KAISER JAMIL AND USHARANI.P. Association of EGFR gene polymorphisms in Head and Neck cancer patients with tobacco and alcohol consuming habits Biology and Medicine 2013; 5: 69-77.

[24] MILLER SA, DYKES DD AND POLESKY HF. A simple salting-out procedure for extracting DNA from human nucleated cells. Nucl.Acid.Res 1988; 16: 1215. http://dx.doi. org/10.1093/nar/16.3.1215

[25] MARTE BM, DOWNWARD J. PKB/Akt: connecting phosphoinositide 3-kinase to cell survival and beyond. Trends in Biochemical Sciences. 1997; 22: 355-358. http://dx.doi. org/10.1016/S0968-0004(97)01097-9

[26] HE Y, VAN'T VEER LJ, MIKOLAJEWSKA-HANCLICH I, VAN VELTHUYSEN ML, ZEESTRATEN EC, et al. PIK3CA mutations predict local recurrences in rectal cancer patients, Clinical Cancer Research 2009; 15: 6956-6962. http://dx.doi. org/10.1158/1078-0432.CCR-09-1165

[27] ALESKANDARANY MA, RAKHA EA, AHMED MA, POWE DG, PAISH EC et al. PIK3CA expression in invasive breast cancer: a biomarker of poor prognosis, "Breast Cancer Research and Treatment 2010; 122: 45-53. http://dx.doi. org/10.1007/s10549-009-0508-9

[28] OGINO S, NOSHO K, KIRKNER GJ, SHIMA K, IRAHARA $\mathrm{N}$ et al. PIK3CA mutation is associated with poor prognosis among patients with curatively resected colon cancer . Journal of Clinical Oncology 2009; 27: 1477-1484. http://dx.doi. org/10.1200/ICO.2008.18.6544

[29] KOZAKI KI, IMOTO I, PIMKHAOKHAM A, HASEGAWA S, TSUDA $\mathrm{H}$ et al. PIK3CA mutation is an oncogenic aberration at advanced stages of oral squamous cell carcinoma," Cancer Science 2006; 97: 1351-1358. http://dx.doi. org/10.1111/j.1349-7006.2006.00343.x

[30] WOENCKHAUS J, STEGER K, WERNER E, FENIC I, GAMERDINGER $U$ et al. Genomic gain of PIK3CA and increased expression of p110alpha are associated with progression of dysplasia into invasive squamous cell carcinoma. J Pathol 2002; 198: 335-342. http://dx.doi.org/10.1002/ path. 1207

[31] ESTILO CL, O-CHAROENRAT P, NGAI I, PATEL SG, REDDY PG et al., „The role of novel oncogenes squamous cell carcinoma-related oncogene and phosphatidylinositol 3-kinase p110alpha in squamous cell carcinoma of the oral tongue," Clinical Cancer Research 2003; 9: 2300-2306.

[32] FENIC I, STEGER K, GRUBER C, ARENS C, and WOENCKHAUS J, Analysis of PIK3CA and Akt/protein kinase B in head and neck squamous cell carcinoma," Oncology Reports 2007; 18: 253-259.

[33] KARAKAS B, BACHMAN KE and Par Mutation BH of the PIK3CA oncogene in human cancers. British Journal of Cancer 2006; 94: 455-459. http://dx.doi.org/10.1038/ sj.bjc. 6602970

[34] SABITHA K,REDDY MVV AND KAISER JAMIL. GST genotypes in head and neck cancer patients and its clinical implications. African Journal of Biotechnology 2008; 7: 3853-3859. 
[35] SABITHA K, VISHNUVARDHAN REDDY M, and KAISER JAMIL. Mutations in XRCC1 gene alters the genetic risks of head and neck cancer patients. Int J. Cancer Research 2009; 5: 58-68. http://dx.doi.org/10.3923/ijcr.2009.58.68

[36] SABITHA K, VISHNUVARDHAN REDDY M, KAISER JAMIL. Smoking related risk involved in individuals carrying genetic variants of CYP1A1 gene in head and neck cancer. Cancer Epidemiology 2010; 34: 5587-592. http://dx.doi. org/10.1016/j.canep.2010.05.002

[37] LLUIS CATASUS, ALBERTO GALLARDO,MIRIAM CUATRECASAS and JAIME PRAT. PIK3CA mutations in the kinase domain (exon 20) of uterine endometrial adenocarcinomas are associated with adverse prognostic parameters Modern Pathology 2008; 21: 131-139.

[38] BADER AG, KANG S, ZHAO L AND VOGT PK. Oncogenic PI3K deregulates transcription and translation. Nat Rev Cancer 2005; 5: 921-929. http://dx.doi.org/10.1038/ $\underline{\operatorname{nrc17}} 153$

[39] LEE JW, SOUNG YH, KIM SY, LEE HW, PARK WS, NAM SW et al. PIK3CA gene is frequency mutated in breast car- cinomas and hepatocellular carcinomas. Oncogene 2005; 24: 1477-1480. http://dx.doi.org/10.1038/sj.onc.1208304

[40] GYMNOPOULOS M, ELSLIGER M-A, VOGT PK. Rare cancer specific mutations in PIK3CA show gain of function. Proc Natl Acad Sci 2007; 104: 5569-5574. http://dx.doi. org/10.1073/pnas.0701005104

[41] NAOMI MARUYAMA, YASUO MIYOSHI, TETSUYATAGUCHI, YASUHIROTAMAKI, MORITO MONDEN, and SHINZABURO NOGUCHI. Clinicopathologic Analysis of Breast Cancers with PIK3CA Mutations in Japanese Women. Clin Cancer Res 2007; 13: 408-414. http://dx.doi. org/10.1158/1078-0432.CCR-06-0267

[42] VIVIAN SZE WING LI, CHI WAI WONG, TSUN LEUNG CHAN, AGNES SZE WAH CHAN, WEI ZHAO, et al. Mutations of PIK3CA in gastric adenocarcinoma. BMC Cancer 2005; 5: 29. http://dx.doi.org/10.1186/1471-2407-5-29

[43] SHAYESTEH L, LU Y, KUO WL, BALDOCCHI R, GODFREY $\mathrm{T}$ et al. PIK3CA is implicated as anoncogene in ovarian cancer. Nat Genet 1999; 21: 99-102. http://dx.doi. org/10.1038/5042 